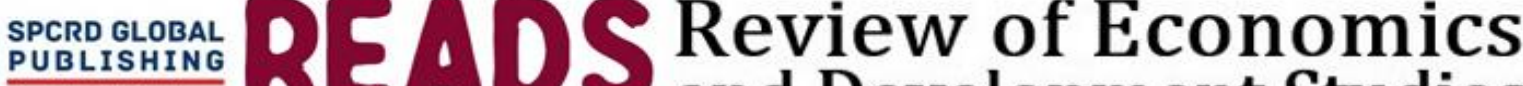

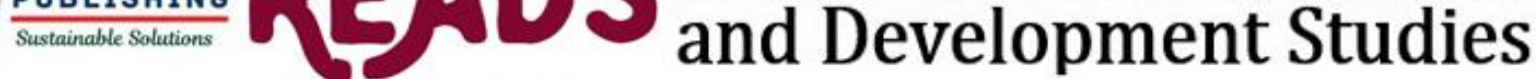

Journal homepage: http://reads.spcrd.org

\section{Factors Contributing Towards Women Employability: An Impact Assessment of a Women Skill Development Training Program}

${ }^{a}$ Fozia Sarwar, ${ }^{b}$ Rana Ejaz Ali Khan

${ }^{a}$ Department of Economics, The Islamia University of Bahawalpur, Bahawalpur, Pakistan Email: sarwerfozia7@gmail.com

${ }^{\mathrm{b}}$ Department of Economics, The Islamia University of Bahawalpur, Bahawalpur, Pakistan Email: ranaejazalikhan@yahoo.com

\begin{tabular}{l} 
ARTICLE DETAILS \\
\hline History: \\
Accepted 30 August 2021 \\
Available Online September 2021
\end{tabular}

Keywords:

Women Employability; Women

Employment; Skill Development

Training

JEL Classification:

E24, J31

DOI: $10.47067 /$ reads.v7i3.397

\begin{abstract}
It is an impact assessment study of a women skill development training program namely District Industrial Homes in Punjab. A quasi experimental (ex post facto) research design has been applied to develop a counterfactual relationship between the outcomes of this program and the demographic and personal characteristics of the women trainees that have get training from the program within time period of 2016 to 2019. The analysis has observed that computer application and stitching/ cutting are most popular trades among women. Further, it has been observed as the time period since the women has gotten training increased the visibility of trained women in market is decreased. The majority of the women were unmarried, of age 15 to 25 years and majority of them have education level intermediate or above. The female work participation was much higher among the women respondents, however, majority of them were unemployed and had no utilization of their skills in daily life business. The data shows that all the unemployed women were unmarried and all the entrepreneur women were either divorced or widow. Another interesting fact have been revealed from the bivariate analysis that all the women that were unemployed have education metric or below metric and all the women that have any employment status have intermediate or above education level. The women employment status has been found more in families with large family size comparatively and all the women that did not practice the veil were unemployed. The female work participation and women employment status have been observed relatively high in low income families. The multinomial regression analysis have established that education level, mother's education level, family size and own family house contribute positively and age dependency ratio, female work participation, veil and family employment (total) has negative impact on women employment status.
\end{abstract}

(C) 2021 The authors. Published by SPCRD Global Publishing. This is an open-access article under the Creative Commons Attribution-

NonCommercial 4.0 


\section{Introduction}

Skill development training is an organized activity that is aimed at imparting knowledge, information and instructions to enhance the recipient's competence, performance and productivity or to help them to attain a required level of knowledge and skills (Ahmed, 2016; Ali et al., 2020). The technical and vocational skill development training prepares an individual for self-reliance and to develop himself or herself as a productive member of the society. In this regard the labor force capability enhancement programs are observing a paradigms shift from curriculum based education to competency based education (Abrar-ul-Haq, Akram, Ashiq, and Raza, 2019). In Pakistan like many of other developing countries the increasing poverty patterns and day by day increasing cost of living are compelling the women to engage in various forms of economic activities through which they can generate income to meet their family welfare and improved standard of living. Even though women are engaged in numerous productive undertakings but the financial return to their efforts are quite minimal (Kaur and Kaur, 2019; Ali, Yusop, Kaliappan, \& Chin, 2020).

In Pakistan generally and in Punjab specifically there are number of programs that have had been initiated by the government to provide the technical and vocational skill development training to the individuals in order to meet the growing needs of the day by day modernizing labor market (Faridi, Chaudhry, and Mumtaz, 2009). However in this respect, Social Welfare \& Bait-ul-Maal Department, Punjab has took the lead by establishing the institutions of skill development specifically for downtrodden, illiterate and economically neglected women of the society (Khan and Ali, 2016). District Industrial Homes in 36 districts of the Punjab are working to impart skill development training to the women, under the administrative control of Social Welfare \& Bait-ul-Maal Department. The scheme of DIH /Sanatzars was launched in 1979. Apart from imparting Trainings in various skills /trades, various saleable articles are prepared by the same trained ladies registered with Sanatzar as workers. The service delivery mechanism of these institutions is producing extra ordinary success stories in the field of women employability, women self-employment and women entrepreneurship.

District Industrial Homes in 36 Districts of Punjab is the targeted intervention that is mainly concerned with imparting skills development and vocational training to the women in different local and marketable trades. The major targets of these institutions include socioeconomic empowerment of local women through skill development training, creating opportunities of self-employment through order work and promotion of local arts, crafts and fusion of these local products with latest market trends. Thus the significance of the current study is that it is determined to relate the outcomes of the aforesaid targets of this program with the personal, demographic, cultural and socioeconomic characteristics of the beneficiaries. The current study has focused the factors that influence or restrict the women participation in the skill development training program. Further importance of the study with respect to empirical literature is that it has focused to determine the determinants of employment of the trained women beneficiaries of the district industrial homes across the Punjab.

Due to increasing scope of skill development training in economic issues like labor force participation, quality of labor force, output growth, employment trade competitiveness, economic growth and economic development it has been appeared as an important area of research. The economic theory and research is giving its due importance to the impact assessment of the skill development and vocational training programs, whereas, as an area of 
research it has not been focused exhaustively as the general education. The female contribution to the socioeconomic development of the economy cannot be ignored. However, the existing cultural, demographic and social barriers did not allow them to grow in society in independent manner. Since majority of women are unskilled so unable to earn and understand their potential rights. Thus, all the programs that are intended to promote women development and women empowerment has made the women skill development training a pivot element of their program policy. In the goal of world community to utilize the potential of this marginalized segment of the society the government of Pakistan is also taking part actively. The initiative of district industrial homes in all 36 districts of Punjab is also the part of these efforts. The current study is impact assessment study of this program namely district industrial homes in Punjab in order to evaluate the program contribution towards the women employment status and income generation activities of the beneficiary women. The main objectives of the study are:

i. To study the profile of the trained women identifying their personal characteristics, demographic characteristics, characteristics related to training, social status and employment status.

ii. To understand the profile and to ascertain the relationship and extent of influence of personal, social, demographic and training related characteristics on women employment status.

iii. To estimate the factors contributing towards women employment status of the trained women.

\section{Literature Review}

Skill development training as a field of research has proved its importance specifically in validation of the models of human capital formation and estimation of investment returns in this regard. The theories of labor economics and empirical investigation in respect of benefits of skill development training have put forth its importance as a distinct field of research.

$\mathrm{Wu}$ (2019) has investigated the role of skill development training in employability of immigrant women in Taiwan. The study adopted the model of contextual development1 for the analysis. The employability has been measured as self-perceived 2 employability on the basis of 4-scale likert scale that included four aspects of respondents perception about their employability. The study concluded that the skill development training in both direct and indirect ways contribute towards the personal and career development of the immigrant women and fostering their needs of enhancing capabilities and empowerment. Likewise, Jabar and Zaza (2015) conducted an impact assessment of the women skill development training program for the refugee women at Zaatari Refugee camp, Jordan. The study observed that the training impact positively to the income generating and economic situation of the women. The training increased their self-confidence and improved their communication, professional, occupational and business skills.

Panitsidou, Vastaki and Valkanos (2012) recorded the views of unemployed women that are skilled and graduate from some technical and skill development program in a case study of Greece. The study observed that majority of the unemployed women was in productive age i-e

1 The development contextual model asserted that individual's personal development is dependent as the contextual perspective of individual personal development and dynamic multilevel contexts.

2 Self perceived employability has been defined as some ones perception about the characteristics of employability that are required to get or hold a designed job. 
20 to 40 years old. Further it is found that in Greece the vocational training is contributing towards improvement in capabilities and skill development among women however its role in tackling female unemployment is limited.

Hilal (2012) highlighted the role of two NGOs in socioeconomic and human development of women in occupied Palestinian Territories. The study stated that the training playing crucial role in increasing the women labor market participation and opportunities of employment. Moreover the study also proved the importance of NGOs in sharing the burden of provision of facilities of skill development and vocational training (See also King and Palmer, 2010; McGralh, 2012; Powel, 2012).

Jain (2015) has tried to evaluate the skill development training program conducted by the NGO namely Maa Durga Shakti Educational Welfare Charitable Trust for the local women in Jaipur, India. The study found that majority of the trained women respondents respond that the training has increased their confidence, improved their communication skills and knowledge about income generation. Likewise, Panwar (2017) conducted the impact evaluation of Krishi Vigyan Kendva (KVK) skill development training program for the rural women in Khandawa District, India. The study concluded that after training the rural women relatively moved to the high levels of employment and income generating activities (see also Sushma, 2007; Deharia, 2009).

Liliane and Mbabazi (2015) studied the impact of AGASKEE project on the women empowerment and employability. The the study concluded that the AGASKEE project impact positively and significantly to the socioeconomic empowerment and employment status of beneficiary women. Khan and Ali (2016) tried to assess the impact of services of Agha Khan Rural Support Program (AKRSP) designated for the welfare and economic empowerment of the local women. Majority of the women responded that training helped them to be economically productive and become socially independent.

Nazir, Vaida and Dar (2012) also tried to assess the impact of skill development training on the lives of women in Indian occupied Kashmir. The authors studied the Krishi Vigyan Kendras (KVK) skill development training program working in Indian occupied Kashmir The training provided the women with adoptable knowledge, confidence and participation in daily life business. The study established that skill development training has positive and significant impact on the socioeconomic uplift of the women through generating means of earning (see also Alese, 2013 for Nigeria; Aslam and Rawal, 2013 for Pakistan).

\section{Research Methodology}

\subsection{Research Design}

The research design of any study is a specific conceptual structure that define the boundaries and limits in which the research is conducted holistically. The present study is designed to do the impact assessment of the women skill development program that is a social intervention of the social welfare \& Bait-ul-Maal Department, Govt of Punjab. As per requirement of the objectives of the study ex-post facto research design has been adopted for the purpose of impact assessment of the district Industrial homes in Punjab. 


\subsection{Population of the Study}

The population of the study are the women which have attained training in any trade from the District Industrial Homes in Punjab in the three years period of 2016 to 2019. Thus all the beneficiary women of the skill development training program in period 2016 to 2019 form the population of the study.

\subsection{Sampling Procedure}

For the purpose of sampling procedure the stratified random sampling technique has been applied. In the present study population of the study is women beneficiaries of district industrial homes in Punjab that are situated in all 36 districts of Punjab. Administratively, Punjab consists of 9 divisions and all 36 districts are divided among these 9 administrative units. The all 9 divisions of Punjab have taken as strata and minimum one district has been selected from each division randomly. In this way total 10 district industrial homes from 10 different districts have been selected for the study. These districts are Lahore, Sahiwal, Bahawalpur, Rajanpur, Muzaffargarh, Faisalabad, Sargodha, Chakwal, Narowal and Rahimyar Khan. In start it was decided to select randomly 10 percent of the women as sample from each selected District industrial home who have get training in period 2016 to 2019. But during the survey it become much harder to approach these women. The contact number of majority of them was not responding, many of them have not given their address to the institution and many of them were not willing to respond for the research purpose. Thus data for the study was selected purposively from the women who were registered at the center for center work/ order work, from the women that usually were in touch with the teachers, incharges or other females' student getting training there. Moreover the women enrolled at the center also helped a lot in data collection and it became easy with their help to approach the women at their homes for data collection. In this way data was collected from 1431 women respondents through a structured questionnaire.

\section{Results and Discussion}

In society majority of the women are contributing to the daily business of life as per their capability, capacity and prescribed social gender role, however, majority of them did not have opportunities to involve in paid economic activities. Keeping in view the contribution of women in family economic activities, whether in direct or indirect way, the women employment status has been categorized in five employment categories, i.e. unemployed, unpaid family job, self employed, wage earner and entrepreneur.

\subsection{Bivariate Analysis}

The bivariate relationship between multiple categories of women employment status and the considered factors for the analysis has been given in ensuring paragraphs one by one.

In the Table 1 the analysis of Bivariate Relationship between employment status and training course is given. The majority women respondents who had achieved the employability status had get training in the courses of embroidery/knitting, English Grammar/speaking, fine arts and stitching/cutting. Further it has been observed from the analysis that majority women which were self-employed had attained training in the courses of stitching/cutting and tailoring. It is pertinent to mention here that all the women who had attained training in the courses of aerobics/gym, beautician and computer application all of them were unemployed. 
Table 1: Women Employment Status and Training Course

\begin{tabular}{|c|c|c|c|c|c|c|c|c|c|c|c|}
\hline \multirow[b]{2}{*}{$\begin{array}{c}\text { Women } \\
\text { Employment } \\
\text { Status }\end{array}$} & \multicolumn{10}{|c|}{ Training course } & \multirow[b]{2}{*}{ Total } \\
\hline & $\begin{array}{c}\text { Aerobics/ } \\
\text { Gym }\end{array}$ & Beautician & $\begin{array}{c}\text { Computer } \\
\text { Aapplication }\end{array}$ & cooking & $\begin{array}{c}\text { Dress } \\
\text { designing/ } \\
\text { Craft } \\
\text { designing }\end{array}$ & $\begin{array}{c}\text { Embroidry/ } \\
\text { knitting }\end{array}$ & \begin{tabular}{|c} 
English \\
Grammer/ \\
Speaking
\end{tabular} & $\begin{array}{l}\text { Fine } \\
\text { Arts }\end{array}$ & $\begin{array}{l}\text { Stitching/ } \\
\text { Cutting }\end{array}$ & tailoring & \\
\hline Unemployed & 10 & 319 & 429 & 14 & $\mathrm{o}$ & $\mathrm{O}$ & $\mathrm{O}$ & $\mathrm{O}$ & $\mathrm{O}$ & $\mathrm{O}$ & 772 \\
\hline $\begin{array}{c}\text { Family Job } \\
\text { Unpaid }\end{array}$ & o & $\mathrm{o}$ & $\mathrm{O}$ & 49 & 61 & 44 & o & $\mathrm{o}$ & $\mathrm{o}$ & $\mathrm{o}$ & 154 \\
\hline Wage Earner & $\mathrm{O}$ & $\mathrm{O}$ & $\mathrm{O}$ & $\mathrm{O}$ & $\mathrm{O}$ & 28 & 24 & 36 & 141 & $\mathrm{o}$ & 229 \\
\hline $\begin{array}{c}\text { Self } \\
\text { Employed }\end{array}$ & o & $\mathrm{o}$ & $\mathrm{o}$ & $\mathrm{o}$ & o & $\mathrm{o}$ & o & $\mathrm{o}$ & 223 & 23 & 246 \\
\hline Entrepreneur & $\mathrm{O}$ & $\mathrm{O}$ & $\mathrm{O}$ & $\mathrm{o}$ & $\mathrm{o}$ & $\mathrm{O}$ & $\mathrm{O}$ & $\mathrm{O}$ & $\mathrm{O}$ & 30 & 30 \\
\hline Total & 10 & 319 & 429 & 63 & 61 & 72 & 24 & 36 & 364 & 53 & 1431 \\
\hline
\end{tabular}

An important fact had been observed during the analysis that all the women who have established entrepreneurship all of them were skilled in tailoring training course.

Table 2: Women Employment Status and Year of Training

\begin{tabular}{|c|c|c|c|c|c|}
\hline \multirow{2}{*}{ Employment Status } & \multicolumn{3}{|c|}{ Year of Training } & \multirow{2}{*}{ Total } \\
\cline { 2 - 5 } & $\mathbf{2 0 1 6}$ & $\mathbf{2 0 1 7}$ & $\mathbf{2 0 1 8}$ & $\mathbf{2 0 1 9}$ & \\
\hline Unemployed & 140 & 126 & 220 & 286 & 772 \\
\hline Family Job Unpaid & 4 & 63 & 31 & 56 & 154 \\
\hline Wage Earner & 40 & 44 & 63 & 82 & 229 \\
\hline Self Employed & 43 & 40 & 58 & 105 & 246 \\
\hline Entrepreneur & 4 & 12 & 4 & 10 & 30 \\
\hline Total & 231 & 285 & 376 & 539 & 1431 \\
\hline
\end{tabular}

The Table 2 has explained that majority of women get training in year 2019 and majority of them, more than 50 percent of them, were utilizing their skills in one way or the other. Out of total 264 self employed women 105 women were graduated from the training program in year 2019. Similarly, most of the wage earner women were also graduate from training program in year 2019. Withal, most of the entrepreneur women had attained training in year 2017 from the women skill development training program, district industrial home.

Table 3: Women Employment Status and Reason of Training

\begin{tabular}{|c|c|c|c|c|c|c|c|}
\hline Employment Status & $\begin{array}{c}\text { any } \\
\text { other } \\
\text { reason }\end{array}$ & $\begin{array}{c}\text { because of } \\
\text { financial } \\
\text { incentive }\end{array}$ & $\begin{array}{c}\text { for self } \\
\text { employment }\end{array}$ & $\begin{array}{l}\text { for time } \\
\text { pass }\end{array}$ & $\begin{array}{c}\text { to get some } \\
\text { job }\end{array}$ & $\begin{array}{c}\text { to have skill } \\
\text { for personal } \\
\text { use }\end{array}$ & Total \\
\hline Unemployed & 31 & 72 & 102 & 38 & 402 & $\mathrm{O}$ & 772 \\
\hline Family Job Unpaid & $\mathrm{O}$ & $\mathrm{O}$ & 127 & $\mathrm{O}$ & 154 & $\mathrm{O}$ & 281 \\
\hline Wage Earner & $\mathrm{O}$ & $\mathrm{O}$ & $\mathrm{O}$ & $\mathrm{O}$ & 28 & 201 & 229 \\
\hline Self Employed & $\mathrm{O}$ & $\mathrm{O}$ & $\mathrm{O}$ & $\mathrm{O}$ & $\mathrm{O}$ & 246 & 246 \\
\hline Entrepreneur & $\mathrm{O}$ & $\mathrm{O}$ & $\mathrm{O}$ & $\mathrm{O}$ & $\mathrm{O}$ & 30 & 30 \\
\hline Total & 31 & 72 & 229 & 38 & 584 & 477 & 1431 \\
\hline
\end{tabular}

The women respondents were asked about the reason due to which they decided to participate in women skill development training program. It is observed that majority of the women respondents which were unemployed during the survey responded that their reasons of training were for time pass, for self-employment, because of financial incentive and any other reason. All the women who were able to secure any employment status were those women who 
have responded during analysis that their reasons of training were to get some job and to have skill for personal use.

Table 4: Women Employment Status and Age

\begin{tabular}{||c|c|c|c|c|c|}
\hline \multirow{2}{*}{ Employment Status } & \multicolumn{4}{|c|}{ Age } & \multirow{2}{*}{ Total } \\
\cline { 2 - 5 } & $\mathbf{1 5} \leq$ & $\mathbf{1 5 - 2 5}$ & $\mathbf{2 5 - 3 5}$ & $\mathbf{3 5 - 4 5}$ & \\
\hline Unemployed & 11 & 557 & 177 & $\mathbf{2 7}$ & 772 \\
\hline Family Job Unpaid & 1 & 119 & 30 & 4 & 154 \\
\hline Wage Earner & 6 & 170 & 45 & 8 & 229 \\
\hline Self Employed & 2 & 187 & 51 & 6 & 246 \\
\hline Entrepreneur & $\mathrm{O}$ & $\mathbf{2 5}$ & 3 & $\mathbf{2}$ & 30 \\
\hline Total & 20 & 1058 & 306 & 47 & 1431 \\
\hline
\end{tabular}

The Table 4 describes that majority of women were of age 15 to 25 years and maximum number of employed women also belonged to this age braket

Table 5: Women Employment Status and Marital Status

\begin{tabular}{|c|c|c|c|c|}
\hline \multirow{2}{*}{ Employment Status } & \multicolumn{3}{|c|}{ Marital Status } & \multirow{2}{*}{ Total } \\
\cline { 2 - 4 } & Divorced/Widow & Married & Unmarried & \\
\hline Unemployed & $\mathrm{O}$ & $\mathrm{O}$ & 772 & 772 \\
\hline Family Job Unpaid & $\mathrm{O}$ & $\mathrm{O}$ & 154 & 154 \\
\hline Wage Earner & $\mathrm{O}$ & 103 & 126 & 229 \\
\hline Self Employed & 6 & 240 & 0 & 246 \\
\hline Entrepreneur & 30 & 0 & 0 & 30 \\
\hline Total & 36 & 343 & 1052 & 1431 \\
\hline
\end{tabular}

As so far marital status of respondent women concerned it has been observed that all of the unemployed women were unmarried. Moreover, all the women involved in unpaid family job were also unmarried. All the married women were employed. There were 30 women which have established entrepreneurship and all of them were either divorced or widow.

Table 6: Women Employment Status and Education Level.

\begin{tabular}{|c|c|c|c|c|c|c|}
\hline \multirow{2}{*}{ Employment Status } & \multicolumn{5}{|c|}{ Education Level } & \multirow{2}{*}{ Total } \\
\cline { 2 - 6 } & Illiterate & $\begin{array}{c}\text { Below } \\
\text { primary }\end{array}$ & Primary & Matric & $\begin{array}{c}\text { Inter or } \\
\text { above }\end{array}$ & \\
\hline Unemployed & 37 & 50 & 132 & 470 & 83 & 772 \\
\hline Family Job Unpaid & $\mathrm{O}$ & $\mathrm{O}$ & $\mathrm{O}$ & $\mathrm{O}$ & 154 & 154 \\
\hline Wage Earner & $\mathrm{O}$ & $\mathrm{O}$ & $\mathrm{O}$ & $\mathrm{O}$ & 229 & 229 \\
\hline Self Employed & $\mathrm{O}$ & $\mathrm{O}$ & $\mathrm{O}$ & $\mathrm{O}$ & 246 & 246 \\
\hline Entrepreneur & $\mathrm{O}$ & $\mathrm{O}$ & $\mathrm{O}$ & $\mathrm{O}$ & 30 & 30 \\
\hline Total & 37 & 50 & 132 & 470 & 742 & 1431 \\
\hline
\end{tabular}

Table 6 shows that all the women respondents who had education level illiterate, below primary, primary and matriculation all of them were observed to have no employment at all. Thus, in society only those women were observed to have employability of their skills who had a good education level besides the skill development training. 
Table 7: Women Employment Status and Family Size

\begin{tabular}{|c|c|c|c|c|c|}
\hline \multirow{2}{*}{ Employment Status } & \multicolumn{4}{|c|}{ Family Size } & \multirow{2}{*}{ Total } \\
\hline & $5 \leq$ & $5-10$ & $10-15$ & $15-25$ & \\
\hline Unemployed & 545 & 227 & $\mathrm{O}$ & $\mathrm{O}$ & 772 \\
\hline Family Job Unpaid & $\mathrm{o}$ & 154 & $\mathrm{O}$ & $\mathrm{O}$ & 154 \\
\hline Wage Earner & $\mathrm{O}$ & 229 & $\mathrm{O}$ & $\mathrm{O}$ & 229 \\
\hline Self Employed & $\mathrm{O}$ & 194 & 52 & $\mathrm{O}$ & 246 \\
\hline Entrepreneur & $\mathrm{O}$ & $\mathrm{o}$ & 16 & 14 & 30 \\
\hline Total & 545 & 804 & 68 & 14 & 1431 \\
\hline
\end{tabular}

Respectively, Table 7 shows that there were 546 women that belonged to the families where in family size was five and below and surprisingly no woman out of them was employed. All the women that were belonged to the families where there in family size was comprised of more than 10 family members were employed and have utilization of their skills. The analysis has clearly established that larger family size is supporting the employability of the skilled women.

Table 8: Women Employment Status and Family Income

\begin{tabular}{|c|c|c|c|c|c|c|}
\hline \multirow[b]{2}{*}{ Employment Status } & \multicolumn{5}{|c|}{ Family Income } & \multirow[b]{2}{*}{ Total } \\
\hline & $\begin{array}{c}10000 \& \\
\text { below }\end{array}$ & $\begin{array}{c}10000- \\
20000\end{array}$ & $\begin{array}{c}20000- \\
30000\end{array}$ & $\begin{array}{c}30000- \\
40000\end{array}$ & $\begin{array}{c}40000 \& \\
\text { above }\end{array}$ & \\
\hline Unemployed & $\mathrm{O}$ & 67 & 408 & 106 & 191 & 772 \\
\hline Family Job Unpaid & $\mathrm{O}$ & 134 & $\mathrm{O}$ & $\mathrm{O}$ & 20 & 154 \\
\hline Wage Earner & $\mathrm{O}$ & 149 & o & $\mathrm{O}$ & 80 & 229 \\
\hline Self Employed & 118 & 60 & $\mathrm{O}$ & 66 & 2 & 246 \\
\hline Entrepreneur & 23 & $\mathrm{O}$ & $\mathrm{O}$ & 7 & $\mathrm{O}$ & 30 \\
\hline Total & 141 & 410 & 408 & 179 & 293 & 1431 \\
\hline
\end{tabular}

Table 8 provides the analysis of Bivariate Relationship between employment status and family income of the women respondents. It is clear from the table that women employment was high in low income families and unemployment is high in relatively high family income categories.

Table 9: Women Employment Status and Own Family House

\begin{tabular}{||c|c|c|c|}
\hline \multirow{2}{*}{ Employment Status } & \multicolumn{2}{|c|}{ Own Family House } & \multirow{2}{*}{ Total } \\
\cline { 2 - 4 } & 0 & 1 & 772 \\
\hline Unemployed & 206 & 566 & 154 \\
\hline Family Job Unpaid & 0 & 154 & 229 \\
\hline Wage Earner & 0 & 229 & 246 \\
\hline Self Employed & 0 & 246 & 30 \\
\hline Entrepreneur & 0 & 30 & 1431 \\
\hline Total & 206 & 1225 & \\
\hline
\end{tabular}

Table 9 shows that there were 206 women that responded that they were living in the house that was not owned by their family and all of these women were found unemployed and have no use of their skills. 
Table 10: Women Employment Status and Female Work Participation

\begin{tabular}{|c|c|c|c|}
\hline \multirow{2}{*}{ Employment Status } & \multicolumn{2}{|c|}{ Female Work Participation } & \multirow{2}{*}{ Total } \\
\cline { 2 - 4 } & $\mathbf{0}$ & $\mathbf{1}$ & 772 \\
\hline Unemployed & 287 & 485 & 154 \\
\hline Family Job Unpaid & 0 & 154 & 229 \\
\hline Wage Earner & 0 & 229 & 246 \\
\hline Self Employed & 0 & 246 & 30 \\
\hline Entrepreneur & 0 & 30 & 1431 \\
\hline Total & 287 & 1144 & \multirow{2}{*}{} \\
\hline
\end{tabular}

Further Table 10 shows analysis of Bivariate Relationship between women employment status and female work force participation. The women respondents were asked whether their families allowed them to participate in work outside home and 287 women had told that they were not allowed to work outside home. All of these women were observed unemployed and no utilization of their skills at all.

Table 11: Women Employment Status and Veil

\begin{tabular}{|c|c|c|c|}
\hline \multirow{2}{*}{ Employment Status } & \multicolumn{2}{|c|}{ Veil } & \multirow{2}{*}{ Total } \\
\cline { 2 - 4 } & $\mathbf{0}$ & $\mathbf{1}$ & 772 \\
\hline Unemployed & 336 & 436 & 154 \\
\hline Family Job Unpaid & 0 & 154 & 229 \\
\hline Wage Earner & 0 & 229 & 246 \\
\hline Self Employed & 0 & 246 & 30 \\
\hline Entrepreneur & 0 & 30 & 1431 \\
\hline Total & 336 & 1095 & \\
\hline
\end{tabular}

The results in Table 11 has described that there exists cultural domination of the norm of veil among women as majority of the women carry veil while visiting outside of the home. However, a surprising fact have been observed during the analysis that there were 336 women which did not carry veil and all of them were observed to have no employment status at all.

\subsection{Multinomial Logistic Regression Analysis}

In this section analysis has been extended to the multinomial logistic regression analysis. In the data set the women employment status has been categorized as unemployed, family job unpaid, self-employed, wage earner and entrepreneur. The category of women employment status "unemployed" has been used as base category and the multinomial logistic regression analysis compare the all the other outcomes of the dependent variable with this contrast category and estimates are discussed in reference to this common reference category (Greene, 2012). In the current analysis the odd ratios have been utilized to interpret the regression estimates instead of regression coefficients.

The predicted values of odd ratios for the women employment status has been obtained by application of R-Studio 3.04 and results are reported in the Tables 12(a,b,c,d). 
Table 12a: Results of Multinomial Logistic Regression Analysis

\begin{tabular}{|c|c|c|c|c|}
\hline \multicolumn{5}{|c|}{ Women Employment Status: Case-1: Family Job Unpaid Relative to Base Level } \\
\hline Predictors & Estimate & Odd Ratios & Std. Error & P-value \\
\hline (Intercept) & -1.93356 & 0.1446 & 0.897235 & 0.03116 \\
\hline EDUL & 0.01448 & 1.0145 & 0.130231 & 0.911465 \\
\hline FEDUL & -0.04005 & 0.9607 & 0.114456 & 0.726402 \\
\hline MEDUL & 0.519706 & $1.6815^{*}$ & 0.108157 & $1.55 \mathrm{E}-06$ \\
\hline Age & -0.04089 & $0.9599^{*}$ & 0.021026 & 0.051777 \\
\hline FS & 0.350722 & $1.4201^{*}$ & 0.05716 & $8.47 \mathrm{E}-10$ \\
\hline DPNR & -0.02885 & $0.9715^{*}$ & 0.00343 & $4.07 \mathrm{E}-17$ \\
\hline HH & 0.462376 & 1.5878 & 0.388941 & 0.234515 \\
\hline FWP & -1.1519 & $0.3160^{*}$ & 0.25133 & $4.58 \mathrm{E}-06$ \\
\hline Veil & -1.1311 & $0.3226^{*}$ & 0.21359 & $1.19 \mathrm{E}-07$ \\
\hline OFH & 1.053464 & $2.8675^{*}$ & 0.374643 & 0.004925 \\
\hline FEMPL (F) & -0.31258 & 0.7315 & 0.215763 & 0.14742 \\
\hline FEMPL (T) & -0.32043 & $0.7258^{* *}$ & 0.154014 & 0.03748 \\
\hline
\end{tabular}

The results in the $1^{\text {st }}$ case of women employment status, that is family job unpaid, show that he mother's education level has strong significant impact on women employment status. In Case-1 one unit increase in mother's education level leads to 1.6815 times increase in women employment status. The age as a predictor has strong significant impact on women employment status for category of unpaid family job, however, its impact is negative as odd ratios value is less than one. The family size has positive impact on women employment status for category, unpaid family job.

Table 12b: Results of Multinomial Logistic Regression Analysis

\begin{tabular}{|c|c|c|c|c|}
\hline \multicolumn{5}{|c|}{ Women Employment Status: Case-2: Self Employed Relative to Base Level } \\
\hline Predictors & Estimate & Odd Ratios & Std. Error & P-value \\
\hline (Intercept) & 0.531621 & 1.7017 & 0.713457 & 0.456191 \\
\hline EDUL & -0.05586 & 0.9456 & 0.097755 & 0.567706 \\
\hline FEDUL & -0.11402 & 0.8922 & 0.081229 & 0.160414 \\
\hline MEDUL & -0.01469 & 0.9854 & 0.077612 & 0.849904 \\
\hline Age & -0.06871 & $0.9335^{*}$ & 0.01789 & 0.000123 \\
\hline FS & 0.338308 & $1.4025^{*}$ & 0.045247 & $7.61 \mathrm{E}-14$ \\
\hline DPNR & -0.02631 & $0.9740^{*}$ & 0.002715 & $3.29 \mathrm{E}-22$ \\
\hline HH & 0.928208 & $2.5299^{*}$ & 0.38667 & 0.016372 \\
\hline FWP & -0.18568 & 0.8305 & 0.228001 & 0.415421 \\
\hline Veil & -0.70265 & $0.4952^{*}$ & 0.189936 & 0.000216 \\
\hline OFH & -0.31345 & 0.7309 & 0.230936 & 0.174687 \\
\hline FEMPL (F) & -0.25355 & 0.7760 & 0.177862 & 0.153995 \\
\hline FEMPL (T) & -0.27622 & $0.7586^{*}$ & 0.123176 & 0.024928 \\
\hline
\end{tabular}


Table 12c: Results of Multinomial Logistic Regression Analysis

\begin{tabular}{|c|c|c|c|c|}
\hline \multicolumn{6}{|c|}{ Women Employment Status: Case-3: Wage Earner Relative to Base Level } \\
\hline Predictors & Estimate & Odd Ratios & Std. Error & P-value \\
\hline (Intercept) & 1.146641 & $3.1476^{* * *}$ & 0.707439 & 0.105053 \\
\hline EDUL & 0.075392 & 1.0783 & 0.106822 & 0.480334 \\
\hline FEDUL & 0.053379 & 1.0548 & 0.084269 & 0.526448 \\
\hline MEDUL & 0.070212 & 1.0727 & 0.077142 & 0.362739 \\
\hline Age & -0.13885 & $0.8703^{*}$ & 0.020884 & $2.95 E-11$ \\
\hline FS & 0.35835 & $1.4309^{*}$ & 0.045234 & $2.33 E-15$ \\
\hline DPNR & -0.02565 & $0.9746^{*}$ & 0.002717 & $3.71 E-21$ \\
\hline HH & -0.10669 & 0.8988 & 0.288402 & 0.711443 \\
\hline FWP & -0.31494 & 0.7298 & 0.225296 & 0.162141 \\
\hline Veil & 0.141056 & 1.1514 & 0.211053 & 0.503916 \\
\hline OFH & -0.15653 & 0.8551 & 0.24824 & 0.528325 \\
\hline FEMPL (F) & -0.12628 & 0.8813 & 0.167655 & 0.451319 \\
\hline FEMPL (T) & -0.28462 & $0.7523^{*}$ & 0.121115 & 0.018775 \\
\hline
\end{tabular}

Further the analysis provides the evidence of negative association between dependency ratio and women employment status. Similarly female work participation and veil as predictor also have negative impact on women employment status in Case-1. Respectively if women respondents are living in own family house there is probability of 2.8675 times higher women employment status. The predictor family employment (total) has significant and negative impact on women employment status.

The multinomial logistic regression results for women employment status Case-2 of selfemployed are also presented in Table 12. the results indicate that education level, father's education level and mother's education level did not have significant impact on women employment status, however, odd ratios present the negative association between these predictors and women employment status. The age as a predictor has negative impact on women employment status category of self- employed. Likewise odd ratios shows that if there is one unit increase in family size the women employment status increased by 1.4025 times. The dependency ratio has significant negative impact on women employment status. The results indicate that gender of the head of the household has strong positive association with women employment status. If the women do not carry veil while moving outside the house there are 0.4952 times more chances that they are self-employed in comparison to the unemployed women. Respectively family employment (total) has negative impact on women employment status. 
Table 12d: Results of Multinomial Logistic Regression Analysis

\begin{tabular}{|c|c|c|c|c|}
\hline \multicolumn{5}{|c|}{ Women Employment Status: Case-4: Entrepreneur Relative to Base Level } \\
\hline Predictors & Estimate & Odd Ratios & Std. Error & P-value \\
\hline (Intercept) & -9.45555 & $7.83 \mathrm{E}-05^{*}$ & 2.942549 & 0.001312 \\
\hline EDUL & 1.023589 & $2.7831^{* *}$ & 0.484347 & 0.034572 \\
\hline FEDUL & 0.243083 & 1.2752 & 0.22158 & 0.272621 \\
\hline MEDUL & -0.1664 & 0.8467 & 0.179246 & 0.35323 \\
\hline Age & -0.08734 & 0.9163 & 0.055781 & 0.117405 \\
\hline FS & 0.458389 & $1.5815^{*}$ & 0.119128 & 0.000119 \\
\hline DPNR & -0.0564 & $0.9451^{*}$ & 0.012109 & $3.19 \mathrm{E}-06$ \\
\hline $\mathrm{HH}$ & -0.52523 & 0.5914 & 0.706491 & 0.457221 \\
\hline FWP & 2.366812 & 10.6634 & 1.776831 & 0.182847 \\
\hline Veil & 1.170434 & 3.2234 & 0.750193 & 0.118718 \\
\hline $\mathrm{OFH}$ & 1.481797 & 4.4008 & 1.106781 & 0.180624 \\
\hline FEMPL (F) & 0.721442 & $2.0573^{* * *}$ & 0.448903 & 0.108028 \\
\hline FEMPL (T) & -1.0468 & $0.3510^{*}$ & 0.374138 & 0.005144 \\
\hline & $\begin{array}{r}\mathrm{Nu} \\
\mathrm{LR} \text { ch } \\
\text { Pseud } \\
\text { Log lil }\end{array}$ & f Observation & $\begin{array}{l}431 \\
3.775 \\
00902 \\
56.887\end{array}$ & \\
\hline
\end{tabular}

The Table $12 \mathrm{c}$ represents the multinomial logistic regression results for women employment status Case-3; wage earner relative to base level (unemployed). The results shows that even though education level, father's education and mother's education level did not have significant impact on women employment stratus however, the association have been found positive. The first significant predictor in the analysis is age and odd ratios shows that if there is one unit increase in age of the women there is 0.8703 times decrease in women employment status in Case-3 of category wage earner. However, family size has strong positive impact on women employment status, higher the family size higher the probability of women employment status of the wage earner relative to the base level of unemployed. The variable dependency ratio has negative association with women employment status. Likewise, family employment (total) has also strong negative association with women employment status.

The results for women employment status Case- 4 category show that education level has positive impact on women empowerment status. If education level increases by one unit the women empowerment status in Case-4 increased by 2.7831 times. The family size also has positive impact on women employment status, the one unit increase in family size increases the probability of the women being entrepreneur by 1.5815 times relative to unemployed (i.e. base category). However, results show strong negative association between the dependency ratio and women employment status of Case-4. The variables family employment (female) and family employment (total) both have significant impact on women employment status, however, family employment (female) contributes positively and family employment (total) contributes negatively to the women employment status.

\section{Conclusion}

It is an impact assessment study of a women skill development training program namely District Industrial Homes in Punjab. The analysis is categorical in determining the factors of 
women employment status and the variables, i-e. education level, father's education level, mother's education level, age, family size, dependency ratio, female work participation, own family house, veil and family employment has been entered into the analysis as predictors in analyzing the impact outcome. The descriptive states of the data showed that majority of the women has attained training in computer application and stitching/ cutting. The majority of the women responded that they have get the training to get some job. Respectively majority of the women were of age 15 to 25 years and majority of them were unmarried. The education level was also found quite better among the trained women respondents as majority of them have education level intermediate or above. The majority of women respondents belonged to the families where there the family size was 5 to 10 family members. In majority cases head of the household was a male. The veil is dominant cultural practice and majority women belong to the families with good socio-economic status in society.

It has been observed during the bivariate analysis that the trades Aerobics/ Gym, beautician, computer application and cooking were skills of no market return. The trade of stitching/ cutting has been observed as the trade of maximum return as majority self-employed and wage earner women have attained training in this skill, likewise, all the entrepreneur women were observed to have skill of tailoring. The data shows that all the unemployed women were unmarried and all the entrepreneur women were either divorced or widow. Another interesting fact have been revealed from the bivariate analysis that all the women that were unemployed have education metric or below metric and all the women that have any employment status have intermediate or above education level. The women employment status has been found more in families with large family size comparatively. Respectively highest women employment status and female work participation have been observed in low income families. For the purpose to find the cause and affect relationship between women employment status and independent variables multinomial regression analysis have been applied. In the analysis it has been observed that education level, mother's education level, family size and own family house contribute positively and age, dependency ratio, female work participation, veil and family employment (total) has negative impact on women employment status.

\section{References}

Abdelhak, A., Mohammed, T., Mohammed, R., Khalid, S., \& Abderrahim, T. (2015). Quality management in vocational training: Evaluation of a specialized institution in Ict. Procedia-Social and Behavioral Sciences, 191, 1928-1933.

Abrar-ul-Haq, M., Akram, F., Ashiq, U., \& Raza, S. (2019). The employment paradox to improve women's empowerment in Pakistan. Cogent Social Sciences, 5(1), 1-17.

Alam, N. (2015). The role of technical vocational education and training in human development: Pakistan as a reference point. European Scientific Journal, 11(10), 35-50.

Alese, O. D. (2013). Capacity Building and Skill Development among Female Entrepreneurs in Ido Zone, Nigeria: Implication for Adult Education. Mediterranean Journal of Social Sciences, 4(11), 680-684.

Ali, S., Yusop, Z., Kaliappan, S. R., \& Chin, L. (2020). Trade-induced Unemployment in Laborabundant and Capital-abundant OIC Countries: Asymmetric Evidence from Quantile-onQuantile Regression. International Economic Journal, 34(4), 682-702.

Aslam, M., \& Rawal, S. (2013). Preparing Women of Substance? Education, Training, and Labor Market Outcomes for Women in Pakistan. The Lahore Journal of Economics, 18, 93-128.

Badejo, A. F., Majekodunmi, A. O., Kingsley, P., Smith, J., \& Welburn, S. C. (2017). The impact of 
self-help groups on pastoral women's empowerment and agency: A study in Nigeria. Pastoralism: Research, Policy and Practice, 7(1), 28.

Bhuyan, M., Ponnusamy, K., \& Singh, J. (2018). A tool to assess women empowerment due to socio-technological interventions in dairying. Indian Journal of Dairy Science, 71(6), 631636.

Bora, B., Rajesh \& Dixit, V. K. (2011). Development of Vocational Skills and Women Empowerment Through Gender Resource Centres: A Study of Delhi State. Journal of Community Mobilization and Sustainable Development, 6(1), 71-76.

Chaudhry, A. G. 2005. Social Mobilization and Economic Empowerment of Women: A case Study in Selected Areas of AJK. Pak. J. of Soc. Sci. 3(2): 309-313.

Chinen, M., Hoop, T., Alcázar, L., Balarin, M., \& Sennett, J. (2017). Vocational and business training to improve women's labour market outcomes in low- and middle-income countries: a systematic review. Campbell Systematic Reviews, 13(1), 1-195.

Dalmia, K., \& Kumar, R. (2018). Impact Assessment of Vocational Mushroom Cultivation Training Programme on Knowledge Gain of Rural Women. International Journal of Pure \& Applied Biosciences, 6(3), 265-270.

Faridi, M. Z., Chaudhry, I. S. \& Mumtaz, A. (2009). The socio economic and demographic determinants of women work participation in Pakistan: Evidence from Bahawalpur District. A Research Journal of South Asian Studies, 24(2), 351-367.

Garbuja, B. P., \& Pasa, R. B. (2016). Role of Technical and Vocational Education and Training in Women Empowerment: A Case from Bima VDC of Myagdi District, Nepal. Journal of Training and Development, 2, 33.

Hadi, M. Y. A., Hassan, R., Razzaq, A. R. A., \& Mustafa, M. Z. (2015). Application of thinking skills in career: A Survey on Technical and Vocational Education Training (TVET) qualification semi-professional job duties. Procedia-Social and Behavioral Sciences, 211, 1163-1170.

Hilal, R. (2012). Vocational Education and Training for women and youth in Palestine: Poverty reduction and gender equality under occupation. International Journal of Educational Development, 32(5), 686-695.

Jabbar, S. A., \& Zaza, H. I. (2015). Evaluating a vocational training programme for women refugees at the Zaatari camp in Jordan: women empowerment: a journey and not an output. International Journal of Adolescence and Youth, 21(3), 304-319.

Jain, C. (2015). Training and its Impact on Women Empowerment (A study of Maa Durga Shakti Educational Welfare Charitable Trust). International Journal of New Technology and Research, 1(5), 55-58.

Kaur, M., \& Kaur, K. (2019). Study on the Adoption Status of Vocational Training Course on Garment Construction and Enrichment among Rural Women.Journal of Krishi Vigyan, 7(2), 239-242.

Khan, F., Aradi, W., Schwalje, W., Buckner, E., \& Fernandez-Carag, M. (2017). Women's participation in technical and vocational education and training in the Gulf States. International Journal of Training Research, 15(3), 229-244.

Khan, M., \& Ali, Q. (2016). Socio-Economic Empowerment of Women in Pakistan; Evidences from Gilgit-Baltistan. International Journal of Asian Social Science, 6(8), 462-471.

Liliane, U. K., \& Mbabazi, P. (2015). The impact of women economic empowerment projects on their socio-economic development in Rwanda: The case of agaseke project. European Journal of Business and Social Sciences, 4(6), 59-87.

Mathew, P. M. (2013). Training and Empowerment of Rural Women in Kerala: The Level of 
Awareness Created in Terms of Knowledge, Attitude and Practice. International Journal of Scientific and Research Publications, 3(4), 1-4.

Murty, S. R., Sridhar, G., \& Patil, D. V. (2013). Success of Vocational Skill Trainings Leading to Empowering Rural Community - Role of NGO's. International Journal of Humanities and Social Science Invention, 2(11), 16-23.

Najoli, E. (2019). The Effectiveness of Wited Programme on Enrollment of Women in Technical and Vocational Education and Training (TVET). Eurasia Journal of Mathematics, Science and Technology Education, 15(3).

Nazir, T., Vaida, N., \& Dar, M. A. (2012). The impact of vocational training courses on knowledge and adoption of rural women in Kashmir. Journal of Sustainable Society, 1(4), 84-87.

Olagbaju, O. O. (2020). Adult Literacy and Skill Acquisition Programmes as Correlates of Women Empowerment and Self-Reliance in The Gambia. Education Research International, 2020, 1-8.

Panitsidou, E. A., Vastaki, M., \& Valkanos, E. (2012). Vocational Education and Training of Unemployed Women in Greece: An Initial Approach. Procedia - Social and Behavioral Sciences, 69, 1729-1736.

Panwar, A. S. (2017), A Study on Impact of Vocational Training Programme Conducted by KVK for Rural Women in Khandwa Block of Khandwa District of M.P. Ph.D.Thesis Submitted to the Rajmata Vijayaraje Scindia Krishi Vishwa By Department of Agricultural Extension Education Rajmata Vijayaraje Scindia Krishi Vishwa Vidyalaya, Gwalior College of Agriculture Indore (M.P.) 2017

Popescu, M. E., \& Roman, M. (2018). Vocational training and employability: Evaluation evidence from Romania. Evaluation and program planning, 67, 38-46.

Rana, K., Singh, K., \& Dilbaghi, M. (2013). Impact Assessment of Vocational Training on Baking among Urban Women in Haryana. Studies on Home and Community Science, 7(1), 2124 .

Rana, S. (2017). Empowering rural women through entrepreneurship training programmes. Asian Journal of Home Science, 12(1), 155-158.

Riaz, S., \& Pervaiz, Z. (2018). The impact of women's education and employment on their empowerment: an empirical evidence from household level survey. Quality \& Quantity, 52(6), 2855-2870.

Rommes, E., Faulkner, W., \& Van Slooten, I. (2005). Changing Lives: the case for women-only vocational technology training revisited. Journal of Vocational Education \& Training, 57(3), 293-317.

Sultana, A. F. R. I. N., \& Hossen, S. S. (2013). Role of employment in women empowerment: Evidence from Khulna City of Bangladesh. International Journal of Social Science and Interdisciplinary Research, 2(7), 117-125.

$\mathrm{Wu}, \mathrm{Y}$. (2019). Examining self-perceived employability among immigrant women participating in vocational training in Taiwan. International Journal of Training and Development.

Yashaswini, B., \& Aquinas, P. G. (2016). Employability Skills Leading to Empowerment in Beautician Industry A Research Study of Beauty Parlors in Mangalore City. International Journal of Innovative Research in Science and Engineering, 2(10), 120-129. 